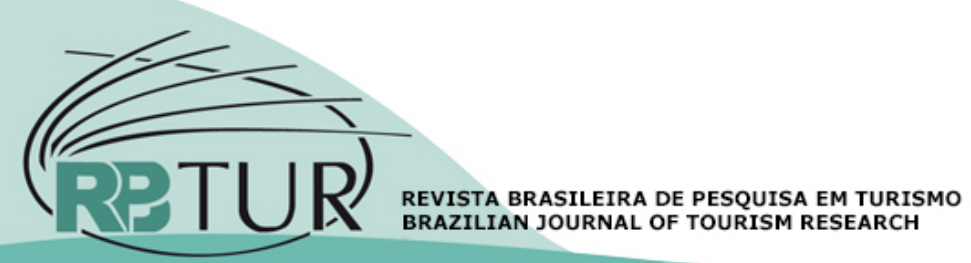

\title{
Artigos
}

\section{Os signos e símbolos do patrimônio nas ações do marketing, uma relação possível? Reflexões a partir das campanhas da Feira Nacional do Doce (Fenadoce) de Pelotas/RS, Brasil}

Heritage signs and symbols in marketing actions: is a relationship possible? Considerations from the advertising of National Sweets Fair (Fenadoce) in Pelotas, RS, Brazil

Los signos y simbolos del patrimonio en las acciones del marketing, una relación posible? Reflexiones a partir de las campañas de la Feria Nacional del Dulce (Fenadoce) de Pelotas / RS, Brasil

\author{
Cristiane Berselli1; Luciano Torres Tricárico1; Diva de Mello Rossini1 ${ }^{1}$
}

1 Universidade do Vale do Itajaí (UNIVALI), Balneário Camboriú, SC, Brasil.

\section{Resumo}

Palavras-chave:

Marketing.

Patrimônio.

Identidade.

Turismo.

Keywords:

Marketing.

Heritage.

Identity.

Tourism.
Este estudo surgiu da necessidade de compreender se o marketing, pautado pela estra-tégia mercadológica, considera os signos e signos patrimoniais para a construção da marca e imagem no turismo. Na busca por responder este questionamento, a metodolo-gia utilizada foi a investigação exploratória de caráter qualitativa, desenvolvido por meio de análise de conteúdo (Bardin, 2011). Foram identificadas as categorias identi-dade, patrimônio e marketing e suas subcategorias a partir da literatura levantada no referencial teórico. Feito isso, foram analisadas as campanhas utilizadas pela Feira Nacional do Doce - Fenadoce, para reconhecer como a identidade e o patrimônio ima-terial da cultura doceira de Pelotas (RS), Brasil, estão sendo inseridos pelos gestores de marketing. Todas as categorias e subcategorias foram encontradas no conteúdo das mensagens, estando mais ou menos explícitas nas cinco campanhas analisadas. Con-clui-se que a relação entre patrimônio e marketing somente será possível se a primeira categoria estiver inserida na segunda. Além de contribuições gerenciais, as categorias e subcategorias encontradas contribuem para pesquisas futuras similares.

Abstract

This study emerges from the need to understand if marketing strategies consider heritage symbols and signs in tourism branding and image building. This is an exploratory study of a qualitative nature using content analysis (Bardin, 2011) to answer the research question. Identity, heritage, and marketing categories and their subcategories were identified in the literature review on the topic. After, the advertising campaigns of Feira Nacional do Doce (Fenadoce) were analyzed, to understand how the identity and intangible heritage of the 'sweet culture' of Pelotas (RS), Brazil, are being used by marketing managers. All categories and subcategories were found, more or less explicitly, in the advertising messages in the five campaigns analyzed. The 
findings suggest that the relationship between heritage and marketing will only be possible if the first category is inserted in the second. In addition to managerial contributions, the categories and subcategories found can be used in similar studies in future research.

Resumen

Palavras clave:

Marketing. Património. Identidad.

Turismo.

Este estudio surgió de la necesidad de comprender si el marketing, pautado por la estrategia mercadológica, considera los signos y signos patrimoniales para la construcción de la marca e imagen en el turismo. En la búsqueda por responder este cuestionamiento, la metodología utilizada fue la investigación exploratoria de carácter cualitativo, desarrollado por medio de análisis de contenido (Bardin, 2011). Se identificaron las categorías identidad, patrimonio y marketing y sus subcategorías a partir de la literatura levantada en el referencial teórico. En este sentido, se han analizado las campañas utilizadas por la Feria Nacional del Dulce - Fenadoce, para reconocer cómo la identidad y el patrimonio inmaterial de la cultura dulce de Pelotas (RS), Brasil, están siendo insertados por los gestores de marketing. Todas las categorías y subcategorías se encontraron en el contenido de los mensajes, estando más o menos explícitas en las cinco campañas analizadas. Se concluye que la relación entre patrimonio y marketing solamente será posible si la primera categoría está insertada en la segunda. Además de contribuciones gerenciales, las categorías y subcategorías encontradas contribuyen a investigaciones futuras similares.

Revisado por pares.

Recebido em: 09/07/2018.

Aprovado em: 17/09/2018.
Como citar Berselli, C.;Tricárico, L. T.; Rossini, D. M. (2019). Os signos e símbolos do patrimônio nas ações do marketing, uma relação possível? Reflexões a partir das campanhas da Feira Nacional do Doce (Fenadoce) de Pelotas/RS, Brasil. Revista Brasileira de Pesquisa em Turismo, São Paulo, 13 (1), p. 72-91, jan./abr. http://dx.doi.org/10.7784/rbtur.v13i1.1479

\section{INTRODUÇÃO}

O homem contemporâneo, principalmente o urbano, se vê em uma realidade cada vez menos centrada em tradições e rituais, em vista disso, busca por mecanismos de reforço de sua auto-identidade (Haobin, Qiu, Huawen \& Goh 2014; Palmer, Koening \& Jones, 2013; Giddens, 2002; Tajfel, 1978). De certa forma, as tipologias de turismo cultural, histórico e patrimonial possibilitam, por um período de espaço e tempo, a vivência de expressões culturais e identitárias mais tradicionais, sejam para residentes revivendo uma tradição, ritual e memórias de tempos passados; ou para turistas que buscam estes tipos de turismo por diversos motivos como experiência, prazer, saciar desejos.

O mundo cada vez mais fluído pelo processo de globalização e pautado pelo consumo se utiliza de elementos patrimoniais que fazem parte da identidade de localidades e comunidades, transformando-os em imagens para serem vendidos como marcas (Giddens, 2002; Canclini, 2001). A partir desse cenário, evidencia-se a importância do patrimônio nas ações de marketing nos destinos e atrativos turísticos, tais como os eventos. O marketing manuseia identidades coletivas para tornarem os destinos competitivos em um mercado consumidor, evidenciando os aspectos individuais de forma a torná-los únicos a fim de despertar os desejos de experiências novas nos turistas (Nicolau Netto, 2016).

No entanto, para o turismo beneficiar a localidade, os residentes necessitam terem sentimento de pertencimento ao seu local de moradia e estarem inseridos na atividade turística (Palmer et al., 2013). Dessa forma, o marketing, além de realizar ações voltadas para atrair turistas, deve se preocupar em incluir os moradores no processo (Machado, Medeiros \& Luce, 2011; Do Valle, Mendes \& Guerreiro, 2012; Wang, Zhou, Lee \& King, 2014).

Feitas essas explanações, este estudo surgiu da necessidade de compreender se o marketing, pautado pela estratégia mercadológica, considera os signos e símbolos patrimoniais para a construção da marca e imagem no turismo (destinos ou atividades turísticas). Para ajudar a elucidar esta questão, o objeto escolhido a ser investigado foi um festival, atividade turística que melhora a economia, a imagem e o posicionamento de mercado dos destinos. Ademais, para López-Guzmán, Prada-Trigo, Pérez-Gálvez \& Pesantez (2017) não existem muitos estudos acadêmicos que realizaram pesquisas empíricas que relacionem patrimônio e turismo e que foquem no patrimônio cultural imaterial. 
O município de Pelotas (RS), Brasil, celebra a cultura doceira realizando anualmente - a Feira Nacional do Doce (Fenadoce) - festival organizado desde 1986, cujo principal objetivo é destacar a produção dos doces pelotenses e desenvolver o turismo no município. Em 2017 recebeu 280 mil visitantes e comercializou 2 milhões e 260 mil doces em 19 dias de evento (Fenadoce, 2017). Ademais, em 15 de maio de 2018, a tradição doceira de Pelotas foi reconhecida como Patrimônio Imaterial Nacional (IPHAN, 2018).

Assim, foram analisados os conteúdos promocionais (2013 a 2017) utilizados pela Festa Nacional do Doce (Fenadoce) em Pelotas/RS, Brasil, para reconhecer como a identidade e o patrimônio da cultura doceira de Pelotas estão sendo inseridas nas campanhas. Quanto aos procedimentos metodológicos, a presente pesquisa é descritiva e exploratória, de caráter qualitativo com utilização da técnica de análise de conteúdo das mensagens segundo Bardin (2011). Através do referencial teórico apresentado, foram identificadas as categorias e as subcategorias sobre identidade, patrimônio e marketing para análise de conteúdo das peças publicitárias. Além de contribuições gerenciais, as categorias e subcategorias encontradas contribuem para pesquisas futuras similares.

\section{IDENTIDADE, CONTEMPORANEIDADE E TURISMO}

A identidade é uma concepção que desafia cientistas das diferentes áreas das ciências humanas, a construção do conceito é um constante desafio dentro da estrutura das pesquisas. Uma definição apresentada por Reed II, Forehand, Puntoni e Warlop (2012:310) dizem que "A identidade pode ser definida como qualquer rótulo de categoria com o qual um consumidor se auto-associe, que é passível de uma imagem clara do que uma pessoa dessa categoria se parece, pensa, sente e faz". Esta é uma definição mercadológica, que se relaciona às relações atuais do indivíduo com o ambiente global.

Para Hall (2006), o mercado global torna as identidades cada vez mais desvinculadas e desalojadas dos lugares e tradições específicas, pois as pessoas têm acesso a novos estilos, são influenciadas pelas imagens de novos lugares vindos pelos meios de comunicação, além do acesso a viagens cada vez mais possíveis. A essa nova identidade o autor chama de "identidade híbrida" e pode ser entendida como "fusão entre diferentes tradições culturais - que são uma poderosa fonte criativa, produzindo novas formas de cultura, mais apropriadas à modernidade" (Hall, 2006:91). Canclini (2001) conceitua hibridação como todo o conjunto de intercâmbios e mesclas culturais que surgem quando há o contato entre culturas e os elementos são tomados "emprestados" umas das outras.

O turismo faz parte de uma interconexão "hospedeiros, hóspedes, construções, objetos e máquinas são contingentemente colocados juntos para produzir certas performances em certos momentos." (Hannam, Sheller \& Urry, 2006:13). O turismo permite uma maior mobilidade entre as pessoas e este deslocamento altera as relações sociais e os processos de produção e consumo, até mesmo a forma de apreciar as culturas, as identidades e interações.

Canclini reflete a respeito de consumo de cultura no mundo globalizado e sobre os interesses de mercado. Para ele, o consumo de bens culturais é a parte final do ciclo econômico também no campo da cultura (Canclini, s/d). O consumo faz parte do mundo globalizado e surge de necessidades e desejos dos consumidores onde os bens culturais funcionam como mercadorias que permitem a experiência, o prazer.

Alguns estudos no turismo buscam entender as motivações relacionadas à identidade que influenciam na escolha de determinados tipos de turismo, como o turismo patrimonial (Bond \& Falk, 2013). Mais do que motivador para a escolha de um segmento turístico, a identidade é fundamental durante toda a experiência turística, pois a partir da experiência os indivíduos podem explorar, manter ou se desvincular dos aspectos ligados à identidade (Bond \& Falk, 2013). No turismo, as identidades (tanto individuais como sociais) são negociadas entre turistas e residentes.

Algumas pesquisas relacionam a identidade social com o conceito de marcas comunitárias (Bagozzi \& Dholakia, 2006). No âmbito do turismo, é possível se investigar os efeitos das imagens gerenciadas pelos destinos turísticos em relação às atitudes dos moradores na promoção da marca dos seus destinos (Palmer et al., 2013). Uma vez que as os destinos têm se tornado marcas, elas se tornam uma fonte de identificação onde os moradores poderão estar emocionalmente ligados e se tornam um mecanismo simples de envolvimento positivo com o turismo (Wang et al., 2014). 
Tajfel (1978:63) define a teoria da identidade social como "parte do autoconceito de um indivíduo que deriva do seu conhecimento de sua pertença a um grupo social (ou grupos), juntamente com o valor e o significado emocional, ligados a essa associação". Significa como o indivíduo define sua auto-identidade e pode estar ligada à religião, associação, etnia, etc (Palmer et al., 2013; Tajfel, 19780).

\subsection{Patrimônio: conceito, produção e consumo}

A legislação brasileira define patrimônio cultural brasileiro como toda a sorte de bens materiais e imateriais, individuais ou em conjunto que tenham identidade, ação e memória relacionadas a diferentes grupos da sociedade brasileira, sejam formas de expressão, modos de criar, fazer e viver, criações científicas, artísticas e tecnológicas, obras, objetos, edificações e demais espaços de manifestações artístico-culturais, conjuntos urbanos e sítios considerados de valor (Brasil, 2010). O patrimônio "é o resultado de um reconhecimento e outorga de valor, o que se dá no âmbito das relações sociais e simbólicas que são tecidas ao redor do objeto ou do evento em si" (Ferreira; Cerqueira \& Rieth, 2008:92), entendido como um esforço de resguardar o passado no presente ou futuro.

O patrimônio cultural imaterial definido pela UNESCO é "as práticas, representações, expressões, conhecimentos e ferramentas que comunidades, grupos e, em certos casos, indivíduos reconhecem como parte de sua herança cultural" (López-Guzmán et al., 2017:569). O patrimônio imaterial não está relacionado aos objetos tangíveis, mas ao universo que envolve esses objetos, que resulta no contexto intangível do patrimônio.

Ao interpretar o turismo patrimonial urbano por meio da política cultural econômica, Su, Bramwell e Whalley (2018) buscaram explicar como se estruturam as relações entre cultura/semiótica, economia e política nas práticas sociais do turismo e do patrimônio urbano em uma visão relacional e de interconectividade. Discutem sobre produção e consumo, significados e representações, poder e governança, e mercantilização, incluindo as reações dos atores.

O patrimônio urbano é entendido como um conjunto de história econômica, sociocultural e política. No urbano se encontra a arte, cultura, tecnologia e organização, são "espaços multidisciplinares físicos, relacionais e governamentais" (Rossi \& Vanolo, 2012:18) que podem atrair turistas. Bianchi (2009) afirma que as pesquisas no turismo precisam ser sensiveis às diversidades culturais e suas subjetividades dentro das sociedades contemporâneas e ao mesmo tempo fundamentada na análise estrutural das forças materiais de poder e desigualdades do capitalismo globalizado e do desenvolvimento do turismo.

0 consumo do patrimônio urbano é o resultado de um processo negociado entre produtor e consumidor que direcionam a experiência turística; ou seja, os produtos do patrimônio urbano são co-criados para a experiência turística. Laing, Wheeler, Reeves e Frost (2014) sugerem que o destino pode ter a capacidade de promover, desenvolver ou mediar ingredientes do destino, que são combinados por cada visitante para criar uma experiência única e individualizada.

Compreende-se que o patrimônio é formado por signos e símbolos. Os signos funcionam como suporte de sentidos e significados de acordo com diferentes códigos culturais. Os códigos são elementos significantes de um determinado sistema (Horta, 2005). Os símbolos possuem conteúdo de significados possível pela consciência e inteligência simbólica humana representando simultaneamente "o real, o imaginário e o desejado; o objetivo e o subjetivo" (Tello Fernández, 2017:06). O signo destaca e salienta, o símbolo designa e dá sentido. O patrimônio como símbolo suscita valores e distinções e direciona comportamentos (Tello Fernández, 2017).

As representações semióticas (signos e símbolos) do patrimônio são importantes para a comercialização das cidades e do turismo (Smith \& Puczkó, 2012; Ismail, Ahmad, \& Hamzah, 2008). As culturas locais, a história e as identidades são selecionadas para comercialização aos turistas e podem não representar o sentido de identidade local dos residentes, mas refletir um capital simbólico coletivo (Su, Bramwell \& Whalley, 2018). Em outras palavras, as marcas de distinção do lugar podem ser significativas pelo poder e os fluxos de capital que podem gerar. No entanto, alguns estudiosos como Nicolau Netto (2016) defendem que a produção no marketing a destinos turísticos só será legítima quando considerar a identidade e a memória coletiva do lugar. 


\subsection{Marketing, ideologias e relações no turismo}

O marketing vem sendo amplamente utilizado por cidades, regiões e países como estratégia para definir uma imagem diferenciadora dos demais destinos considerados concorrentes. Para Ramos e Fernandes (2014), a globalização e turismo trazem a necessidade de inovação, condição indispensável para a sobrevivência e desenvolvimento empresarial e institucional que fazem parte da atividade turística. Neste processo, há necessidade de se ter diferenciais turísticos que se destaquem dos demais.

Machado et al. (2011) lembram que o cerne do marketing enfatiza a relação entre consumidor e fornecedor; contudo, no cenário complexo do turismo existem diferente atores envolvidos como turistas, órgãos públicos, empresas privadas e moradores. Nestas relações ocorrem trocas tangiveis e intangiveis complexas, interações sociais, econômicas, ambientais e intercâmbios simbólicos entre culturas e identidades.

Para Marion (2006), o marketing é uma "ciência performativa", por se conceitualizar e se expressar ao mesmo tempo na economia de mercado; em outras palavras, é uma prática de gestão equipada pela ciência. 0 autor supracitado afirma que o marketing não se vê como uma ideologia, todavia pode ser interpretado em três esperas: como prática (ações dos profissionais do marketing), como ramo do conhecimento (por seguir princípios e códigos, como, por exemplo, o mix do marketing) e é uma ideologia (pela elaboração de crenças duradouras e representações coletivas compartilhadas).

O estudo de Levy \& Luedicke (2013), apoiado em Crockett e Wallendorf (2004), considera que a ideologia de marketing é definida como uma visão de mundo que inclui ideias e valores que coexistem e são usados publicamente para justificar as ações de marketing que são moldadas por interações de mercado e regulamentos políticos. São definidos objetivos, estratégias e objetos de pesquisa pautados por uma narrativa de como o marketing contribui para o aumento de riqueza de uma nação (Crockett \& Wallendorf 2004). Definição esta que vai ao encontro do pensamento de Nicolau Netto (2016), pois os agentes de marketing produzem seus discursos de legitimidade de acordo com seus interesses, com propósitos de geração de lucro.

Ao analisar o marketing de lugares, Nicolau Netto (2016:500) afirma que "Esse campo é mobilizado a produzir simbolicamente um tipo de lugar, cada vez mais o lugar-modelo em um imaginário global". Na busca pela diferença é que o trabalho do marketing ganha espaço e justifica suas atividades nos destinos; entretanto, é importante evidenciar que a "diferença produzida pelos publicitários só pode ser legítima uma vez que demonstre alguma relação com uma memória coletiva, minimamente reconhecível nacional e internacionalmente." (Nicolau Netto, 2016:503).

Para os autores Machado et al. (2011), a área de investigação do destination branding passa por uma "miopia" do marketing de destinos ao negligenciar algumas questões importantes como: não considerar a oferta dos concorrentes; negligenciar os residentes ao concentrar a atenção aos turistas; e desconsiderar questões sociais mais amplas. Os autores chamam a atenção para que a percepção dos residentes sejam colocadas em evidência durante o processo de elaboração do branding ao construir a imagem do destino turístico, pois são esses atores que dão significado sobre seu próprio espaço.

Carvalho, Ferreira e Figueira (2011:460) destacam que diversos autores concordam sobre o "crescente contributo da cultura local, recursos endógenos do destino turístico, recursos intangiveis e o papel proativo da comunidade local na formação de uma imagem diferenciadora do destino turístico". A imagem influencia a escolha do turista e é entendida como as percepções e expectativas do turista sobre o destino (Buhalis, 2000). Para a promoção turística são utilizadas ferramentas que articulem a imagem do destino à identidade cultural (Zucco, Quadros, Schmitt \& Fiuzza, 2017; Lavandoski, Tonini, \& Barretto, 2012). Muitas pesquisas no turismo têm defendido, segundo Zucco et al. (2017), a articulação entre imagem dos destinos, identidade cultural e participação dos residentes.

Em relação à pesquisa sobre os impactos dos eventos na imagem de destinos, Do Valle, Mendes e Guerreiro (2012) argumentam que o envolvimento e a participação dos locais são fundamentais para garantir o sucesso do evento e a comunicação de marketing do evento deve ter como alvo a harmonia com a percepção dos residentes em relação à imagem projetada do evento e não somente focar no turista.

No âmbito do conhecimento e das práticas do marketing, os profissionais trabalham com a construção de uma marca. A marca é utilizada para identificar algo através da soma de diversos atributos, com intuito de 
deixar uma memória duradora na mente do consumidor (Landa, 2006), conhecida como valor de marca (brand equity) (Aaker, 2009; Lee, Yang, Mizeski \& Lambert, 2015; Kotler, 2006). Produtos, serviços, destinos turísticos e eventos podem ser trabalhados por uma marca. A marca tem por objetivo estimular lealdade, garantir qualidade, oferecer percepção de maior valor agregado além de garantir ao consumidor de uma marca a sensação de pertencer a um grupo de valores compartilhados (Healey, 2009).

Para Kapferer (2008), a identidade de uma marca é construída pelo prisma de seis elementos: aparência física, personalidade de marca, cultura de marca, comunicação com clientes, para quem a marca é direcionada (público-alvo) e a autoimagem do consumidor (ligação do consumidor com a marca por identificação) (Janonis, Dovalienė \& Virvilai, 2007).

A marca pode ser interpretada também por dispositivos comerciais que servem para identificar e diferenciar a marca. São os nomes, logomarcas e símbolos, personagens, slogans e jingles, embalagem e sinalização (Keller, Aperia, \& Georgson, 2008). A criação de logotipo, símbolo ou emblema é uma base de qualquer identidade de marca (Buttle \& Westoby, 2006). Estes elementos proporcionam como resultado uma maior exposição da marca, aumentando a velocidade de seu reconhecimento e facilitando sua preferência através do efeito de exposição (Baker, 2003).

0 conceito de marketing, como se percebe, não se resume à promoção, entendida como uma das ações da comunicação do marketing. A comunicação e a propaganda são apenas parte de uma proposta de entrega de valor que necessita contemplar "a elaboração, implementação e controle de planos estratégicos de posicionamento de produtos, serviços e marcas" (Bautzer, 2010, p.26).

Os elementos de sinalização fazem parte das interações comunicacionais da contemporaneidade. A comunicação é fenômeno complexo, considerando a interpretação e a própria comunicação como parte dos mecanismos de interação social (McLuhan, 1967, 1994). Os meios de comunicação influenciam a vida social e as instituições: por um lado, pelo acesso à informação e conhecimento, por outro, por aumentar as formas de interação e integração social que condicionam percepções e interpretações de mensagens (McLuhan, 1967, 1994). Os meios são cada vez mais "extensões do homem" devido à velocidade de mudanças nas comunicações e as novas linguagens e suportes de conteúdo entregues aos consumidores (McLuhan, 1967,1994).

\section{METODOLOGIA}

A presente pesquisa é exploratória, caracteriza-se como descritiva e qualitativa, com a utilização da técnica de análise de conteúdo (Prodanov \& Freitas, 2009; Gil, 2008). A pesquisa qualitativa proporciona a compreensão da linguagem, das percepções e valores, a pesquisa exploratória tem como objetivo fundamental ampliar, esclarecer e modificar conceitos e ideias (Gil, 2008).

Para a pesquisa documental foram utilizados dados primários e secundários que permitiram responder aos objetivos da pesquisa. Os dados primários são os dados originais, as informações que não tenham sua estrutura modificada, obtidos em revistas científicas, literatura acadêmica, livros (documentos escritos) e, também, fotografias, filmes, vídeos (documentos não escritos), entre outros (Veal, 2011; Decker, 2003). Os dados secundários são os que já passaram por análise crítica, como os relatórios. Portanto, foi utilizado principalmente dados primários, entre documentação escrita para elaboração do referencial teórico e, pesquisa em sites online para identificação e análise das peças das campanhas da Fenadoce de 2013 a 2017.

O recorte temporal transversal com perspectiva longitudinal foi entendido como suficiente para atingir os objetivos da pesquisa. A interpretação dos dados foi realizada a partir da análise de conteúdo segundo Bardin (2011), obedecidas as fases: 1) Pré-análise com a escolha dos materiais promocionais; 2) Exploração do material seguindo as categorias definidas segundo a literatura encontrada. Quanto a análise de conteúdo, Bardin (2011, p. 15) enfatiza que "a análise do conteúdo é um conjunto de instrumentos de cunho metodológico em constante aperfeiçoamento, que se aplicam a discursos (conteúdos e continentes) extremamente diversificados". 
Nesse trabalho, as categorias foram articuladas a partir do referencial teórico apresentado: identidade, patrimônio e marketing. As deduções lógicas ou inferências que serão obtidas a partir das categorias serão responsáveis pela identificação das questões relevantes contidas no conteúdo das mensagens.

Quadro 1 - Categorias e subcategorias para análise de conteúdo das mensagens:

\begin{tabular}{|c|c|c|}
\hline Categorias & Subcategorias & Referências \\
\hline Identidade & $\begin{array}{l}\text { Identidade híbrida } \\
\text { Experiência } \\
\text { Auto-identidade/auto-associação }\end{array}$ & $\begin{array}{l}\text { Hall (2006) } \\
\text { Canclini (2001) } \\
\text { Tajfel (1978) }\end{array}$ \\
\hline Patrimônio & $\begin{array}{l}\text { Bens materiais e Bens imateriais } \\
\text { Memória } \\
\text { Modos de criar, fazer e viver/relações sociais } \\
\text { Signos e símbolos }\end{array}$ & $\begin{array}{l}\text { López-Guzmán et al. (2017) } \\
\text { Brasil (2010) } \\
\text { Ferreira et al.(2008) }\end{array}$ \\
\hline Marketing & $\begin{array}{l}\text { Imagem } \\
\text { Ideologia (elaboração de crenças, ideias e valores) } \\
\text { Diferenciação (sentimento de unicidade) } \\
\text { Marca: logotipo, slogan, jingle, embalagem, sinali- } \\
\text { zação }\end{array}$ & $\begin{array}{l}\text { Nicolau Netto (2016) } \\
\text { Levy \& Luedicke (2013) } \\
\text { Marion (2006) } \\
\text { Keller et al. (2008) } \\
\text { Crockett \& Wallendorf (2004) }\end{array}$ \\
\hline
\end{tabular}

As subcategorias foram encontradas através do referencial teórico apresentado dentro dos autores mencionados, podendo estar presentes ou não nas campanhas que serão analisadas, serão consideradas outras subcategorias que poderão aparecer no conteúdo das mensagens. São apresentados as análises das campanhas em estudo e o posterior cruzamento de dados que permitiram a elaboração das considerações finais.

\subsection{A cultura doceira pelotense e a Fenadoce}

Pelotas é o terceiro município mais populoso do Rio Grande do Sul no Brasil e tem sua primeira referência histórica em 1758. 0 consumo dos doces se tornou tradicional a partir do hábito dos charqueadores portugueses servirem os doces finos como demonstração de requinte em banquetes, saraus e reuniões entre a alta sociedade pelotense (IPHAN, 2007). Os doces coloniais de frutas advieram do período do declínio das charqueadas, quando os imigrantes alemães, pomeranos, italianos e franceses desenvolveram a agricultura familiar e utilizaram as frutas para produzir doces (Ferreira; Cerqueira \& Rieth, 2008). Com o declínio da indústria do charque, os doces finos ganham as ruas e passam a ser patrimônio de todas as esferas da sociedade pelotenses (IPHAN, 2007). Além disso, os negros aprenderam a fazer os doces finos e contribuíram na perpetuação, atualização e novos significados ao se utilizarem dos doces nos seus rituais religiosos. Todas essas etnias contribuíram para a formação e renovação da tradição doceira em Pelotas.

Em 2005, durante o processo de inventário da produção de doces tradicionais pelotenses para legitimá-lo como patrimônio imaterial (Ferreira et al., 2008), foi possível identificar a diversidade da tradição doceira, que contempla a região, o meio urbano e o rural. A produção e consumo perpassam por diferentes classes sociais e etnias, em uma conjuntura social e cultural de saberes e fazeres, com trajetória histórica e prática contínua no cotidiano da comunidade. Hoje os doces de Pelotas são importante fonte de renda para muitas pessoas (IPHAN, 2007). Recentemente, em 15 de maio de 2018 a tradição doceira de Pelotas foi reconhecida como Patrimônio Imaterial Nacional (IPHAN, 2018).

Devido à importância da cultura do doce, em 1986 ocorreu a primeira Feira Nacional do Doce (Fenadoce), criada com os esforços do Poder Público, conjuntamente com outras entidades. Quando, em 1995, a Câmara de Dirigentes Lojistas de Pelotas (CDL) assumiu a coordenação do evento, a $4^{\circ}$ Fenadoce obteve um expressivo público de 100 mil visitantes surpreendendo os organizadores. A partir de 1998, a Feira se tornou anual e com espaço próprio (Fenadoce, 2016), profissionalizando o evento, desde os espaços disponibilizados às estratégias de divulgação. 
Para os doceiros, a feira foi um marco pela possibilidade de ampliar e mostrar os seus produtos. Para os organizadores, alcançou-se o objetivo de promover o comércio e a indústria, destacando-se os doces feitos no município. Além disso, é importante atrativo turístico que projeta a imagem de Pelotas e região, fomentando o turismo e a economia local, atraindo a comunidade pelotense, turistas nacionais e dos países do Mercosul1.

Desde a primeira edição, a Feira promove a sua marca, entre elas, estão as intervenções comunicacionais. Em 2007 foi criado um ícone, a Formiga, considerada mascote e embaixadora da marca do festival, tendo em vista que ela é a "persona" nos canais online da Fenadoce no Facebook, Instragram, Twitter e Youtube.

\section{ANÁLISE DE DADOS}

Serão apresentadas as campanhas das edições, analisando os temas (slogans), os cartazes, os textos dos cartazes, a música (jingle) do vídeo comercial e as imagens do vídeo comercial.

\subsection{Campanha de $2013-21^{\circ}$ Fenadoce:}

$\mathrm{Na} 21^{\circ}$ edição da Fenadoce o tema (slogan) foi "A nossa cultura está em festa" e apresenta material em formato de cartaz (figura 1). É possível analisar nos textos o destaque ao aspecto cultural do evento e os doces como sendo um diferencial no contexto. O cartaz traz a frase "A Fenadoce 2013 vai colocar todo mundo na mesma batida. Venha se deliciar com os doces mais gostosos do Brasil em uma festa cheia de sabores, diversão e muita cultura". Quanto às imagens, destacam-se as formigas e em segundo plano se apresentam quindins e símbolos de teatro.

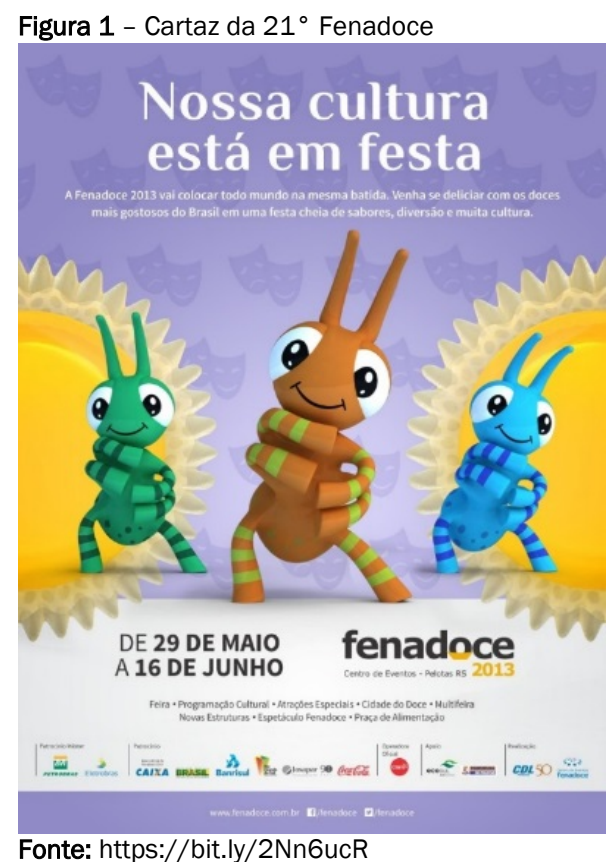

Dos elementos de identidade pode ser percebida a imagem dos dois quindins, remetendo à cultura doceira, principal chamariz e produto oferecido no evento. Tanto o tema como o subtítulo trazem a palavra "cultura". O tema destaca a auto-identidade e a auto-associação ao usar as palavras "nossa cultura", pois a mensagem passa a ideia de ao participar do evento, faz-se parte de um grupo de identidade compartilhada. Além disso, a imagem de plano de fundo das máscaras de teatro faz alusão à cultura, uma vez que o evento possui uma diversidade de apresentações culturais.

\footnotetext{
1 Fonte: Fenadoce (2012). A História da Fenadoce - Por quem a ajudou a construir. Vídeo do lançamento da $20^{a}$ Fenadoce. Disponível em: https://www.youtube.com/watch?v=E7C6MguVBk8
} 
Em relação à mensagem "Venha se deliciar com os doces mais gostosos do Brasil", percebe-se a diferenciação e a ideologia do marketing. A formiga, mascote do evento, é apresentada em primeiro plano, um dos elementos de marca trabalhados pelo marketing. Todas as subcategorias do marketing foram utilizadas.

Quanto à categoria patrimônio, o cartaz não apresenta explicitamente menção às subcategorias, a cultura doceira se apresenta através do símbolo dos doces, assim como a identidade aparecem nas frases num contexto superficial. Os bens materiais são representados pelos doces e os bens imateriais pela palavra "cultura".

O comercial de 30 segundos apresenta uma música "chamando" o público para o evento, faz referência à feitura de um doce de Pelotas; além disso, a formiga da Fenadoce está presente.

Chame os amigos e as amigas, a nossa alegria está feita. Dê passinhos de formiga, pra esquerda e pra direita. Bate as gemas e enrola com carinho, banho na calda e está feito o seu docinho. Não há maior delícia do que esta, na Fenadoce a cultura está em festa.

A música (jingle) é um dos elementos de marca do marketing assim como o mascote. Os aspectos de diferenciação e ideologia aparecem novamente com a frase "não há maior delícia do que esta". Na categoria patrimônio, os modos de criar, fazer e viver aparecem na feitura do doce, caracterizado como patrimônio imaterial. A memória é percebida ao se mencionar as gemas, principal produto dos doces finos de Pelotas, remetendo à cultura portuguesa do período das Charqueadas. A categoria identidade está presente, os doces pelotenses se caracterizam por serem uma cultura híbrida e a música promete a vivência de uma experiência cultural e identitária.

Em relação às características visuais do comercial, é encenada a dança das formigas e gestos da feitura do doce. Demais elementos presentes: quindins, suspiros, pincéis, confetes, garfos, livros e filme/cinema. 0 comercial faz referência à diversidade cultural e gastronômica do evento.

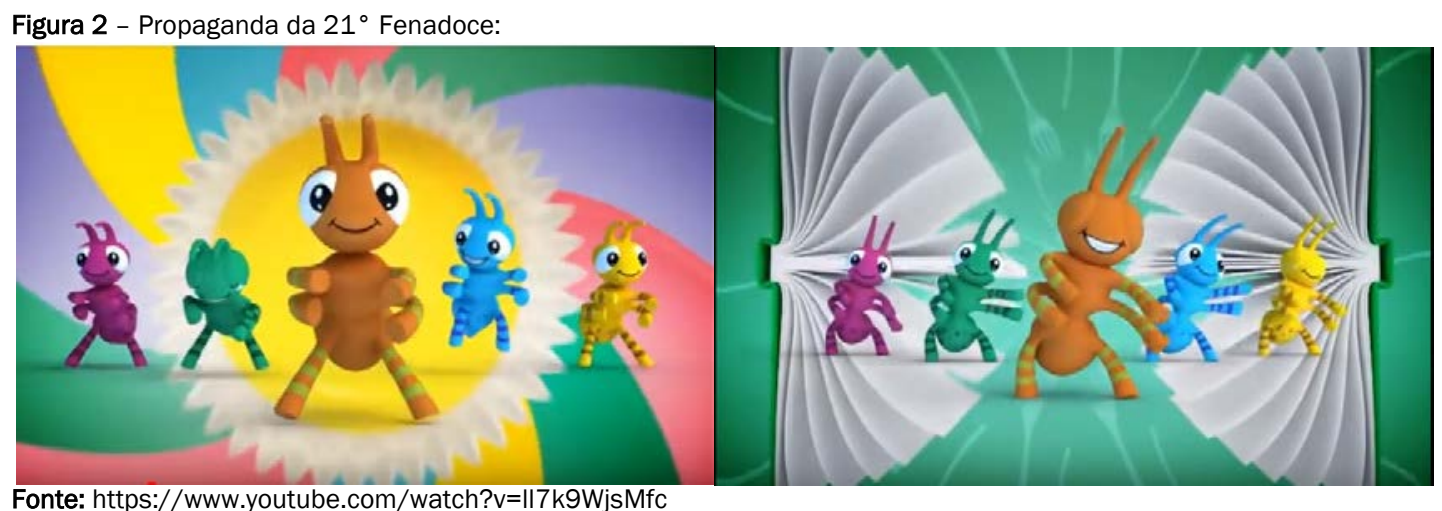

A propaganda explora aspectos digitais, o mascote possui vida e dança com as demais formigas. Os elementos gráficos demonstram de forma simples o que se encontrará no evento, os doces, a gastronomia e variedade de apresentações artísticas. Elementos que identifiquem o patrimônio e a identidade de forma contextualizada e aprofundada não estão presentes nas imagens.

\subsection{Campanha $2014-22^{\circ}$ Fenadoce}

A $22^{\circ}$ Fenadoce trouxe como tema (slogan) "Todos somos doces". Na campanha, as letras do tema e os cenários foram elaboradas fazendo referência a diversos doces. 


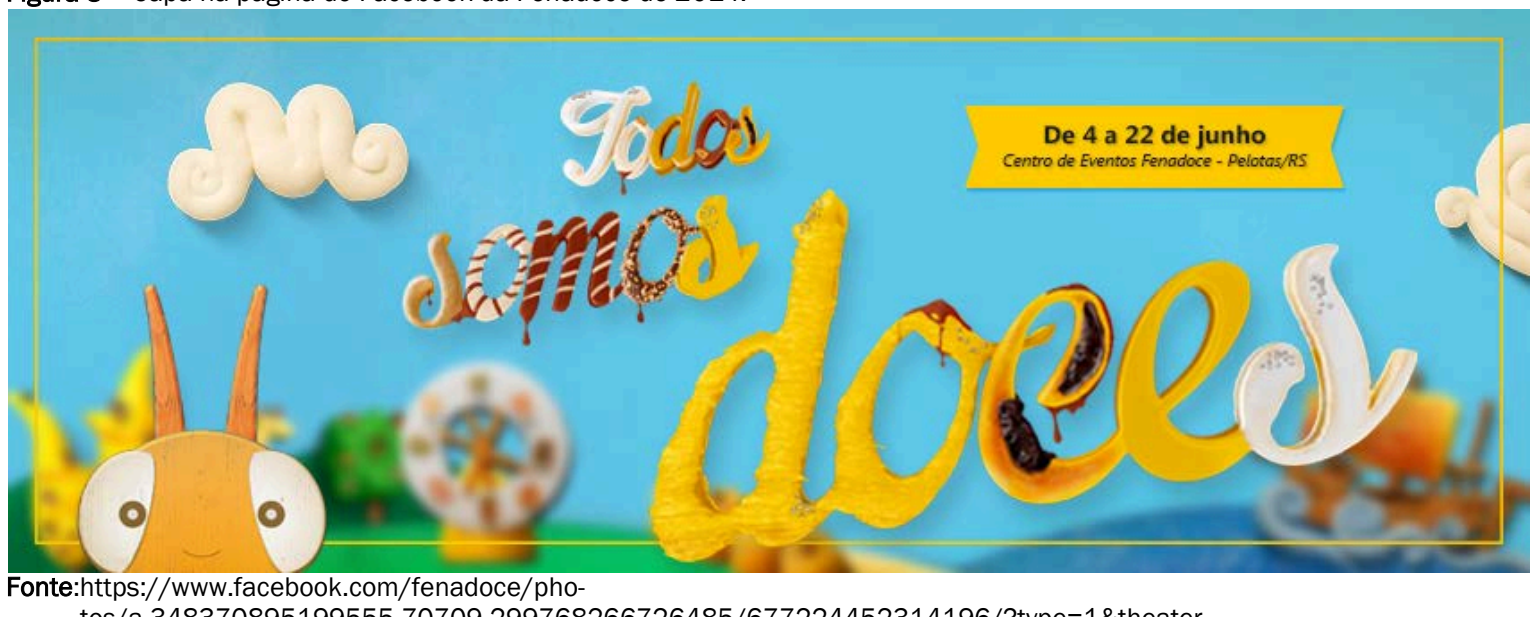

tos/a.348370895199555.70709.299768266726485/677224452314196/?type=1\&theater

O cartaz visualmente utiliza os doces para comporem as letras que estão em primeiro plano. Em "doces" pode-se identificar o ninho, olho de sogra, quindim, bem-casado, os doces de gemas. Na categoria identidade, a cultura e a identidade híbrida são representadas pela alusão aos doces presentes nas letras, enquanto que visualmente se promete uma experiência gastronômica e cultural. A auto-identidade e auto-associação pode ser interpretada através do tema "Todos somos doces".

O plano de fundo mostra uma paisagem com céu azul, nuvens, árvores, moinho, e um mar com um barco que remetem à chegada dos portugueses, aparentemente a vela do barco é uma Fatia de Braga. Em primeiro plano está o mascote: Formiga da Fenadoce, símbolo e ícone do evento. Os bens materiais e imateriais assim como a memória também são representados no cartaz; a categoria patrimônio aparece mais explicitamente com todas as subcategorias sendo representadas.

Ademais, foi ano que ocorreu a Copa do Mundo no Brasil, assim, a campanha buscou explorar as questões de que todos os povos são iguais fazendo um paralelo às diferentes etnias que compõem o patrimônio doceiro de Pelotas.

No comercial, bonequinhos representando as etnias árabe, alemã, francesa, portuguesa e africana estão em primeiro plano, manipulando o que vai se tornando um doce em forma de globo terrestre, em que a última personagem, a formiga, aparece comendo (Figura 4). Os cenários de fundo representam os países das personagens e são elaboradas utilizando doces como: bem casado, fatia de Braga, pastel santa clara, ninho, quindim, camafeu, olho de sogra, além de pedaços de fruta.

Figura 4 - Propaganda da $22^{\circ}$ Fenadoce:

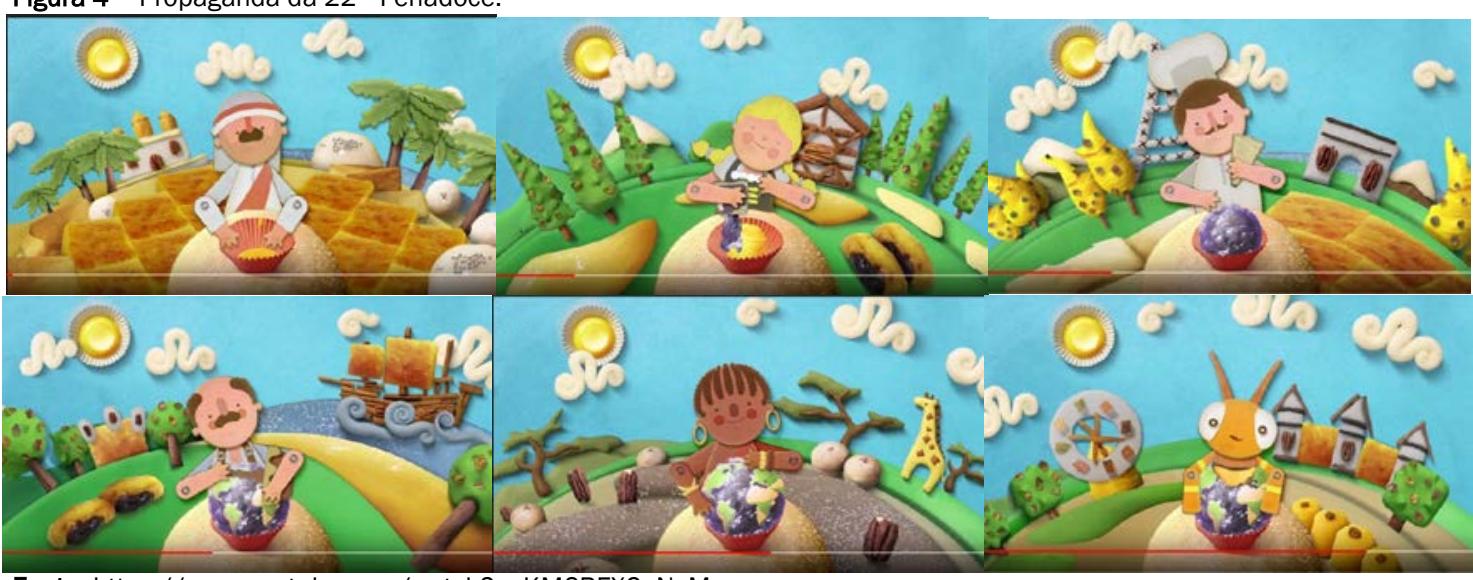

Fonte: https://www.youtube.com/watch?v=KM6RFXCpN_M 
Os árabes não fazem parte das etnias que compõem a cultura doceira pelotense (Ferreira et.al, 2008); apesar disso, historicamente foram eles que introduziram a cana de açúcar na costa oriental do Mediterrâneo (Freyre, 2012; Figueiredo, 2013), matéria prima importante dos doces portugueses (Cavalcanti, 2007; Figueiredo, 2013). Percebe-se que os italianos não foram representados na propaganda.

Apesar de nem todas as etnias serem representadas, a identidade e o patrimônio são identificados nas imagens. Existe fluidez durante a manipulação e “colaboração" das etnias na elaboração do doce, um direto paralelo com o universo que compõe o patrimônio imaterial. Apresentam-se, assim, os modos de fazer, criar e viver, os bens materiais e imateriais, signos e símbolos do patrimônio.

A música (jingle) complementa as imagens visuais do comercial, a auto-identidade e auto-associação da categoria identidade estão presentes e a promessa de uma experiência dos sentidos ao participar do evento. Concomitante está presente a ideologia do marketing.

Todos somos doces porque dentro da gente ninguém é diferente, todos somos doces. Quem pode fazer o nosso mundo melhor se não nós. Venha adoçar o seu coração, na Fenadoce você vai sentir que só basta sorrir.

Esta campanha buscou explorar a doçura das pessoas em relação a sentimentos e atitudes ligadas à palavra “doce”, principal produto do evento.

\subsection{Campanha $2015-23^{\circ}$ Fenadoce:}

A temática da $23^{\circ}$ Fenadoce foi "Uma festa completa". A propaganda desta edição mostra as formigas dançando e trabalhando em conjunto para montarem as peças de um quebra-cabeça que vão mostrando imagens que refletem a diversidade do festival.

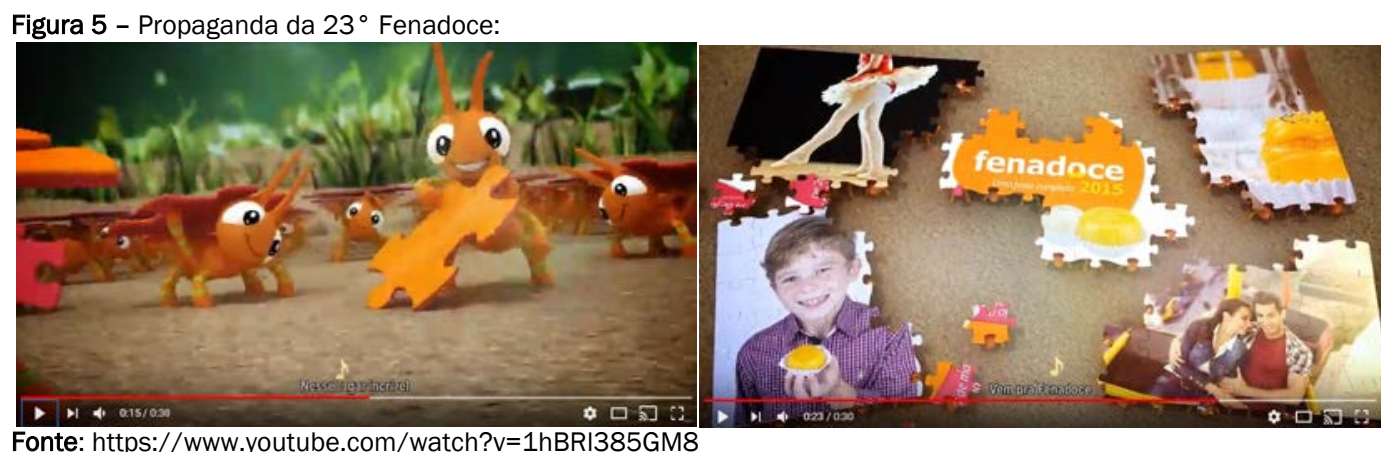

O quebra-cabeça apresenta as imagens de um quindim e fios de ovos, um braço de violão, as pernas de uma bailarina, uma criança oferecendo um quindim e um casal no parque de diversões. 0 jingle reforça a cena da propaganda:

A nossa festa tem sabor que enche os olhos. Todo mundo quer também cultura e diversão, uma doce paixão. É Fenadoce, vem pra Fenadoce. Vem pra se divertir, nesse lugar incrivel, todo mundo vai curtir, é doce a tradição, ninguém resiste não, é Fenadoce, vem pra Fenadoce.

Na música é citada as palavras “cultura e diversão", “doce paixão” e “doce tradição” enquanto nas imagens aparecem cenas de dois doces, alusão à dança, música e o parque de diversões. Embora possa ser percebida a auto-identidade e auto-associação da identidade em "nossa festa" conjuntamente com a ideologia passada pelo marketing, tanto o texto quanto as imagens fazem fracos elos com as questões indentitárias e de patrimônio relacionados ao patrimônio gastronômico pelotense, pois as diferentes opções de entretenimento são os elementos em evidência no comercial.

O cartaz possui a frase "Este ano a Fenadoce está cheia de novidades. Uma festa que só vai ser completa se você participar". Outras informações quanto às novidades da edição do evento são destacadas em três quebra cabeças: Festival Doce Cultura, Museu do Video-game e Festival de Gastronomia Fenadoce. 


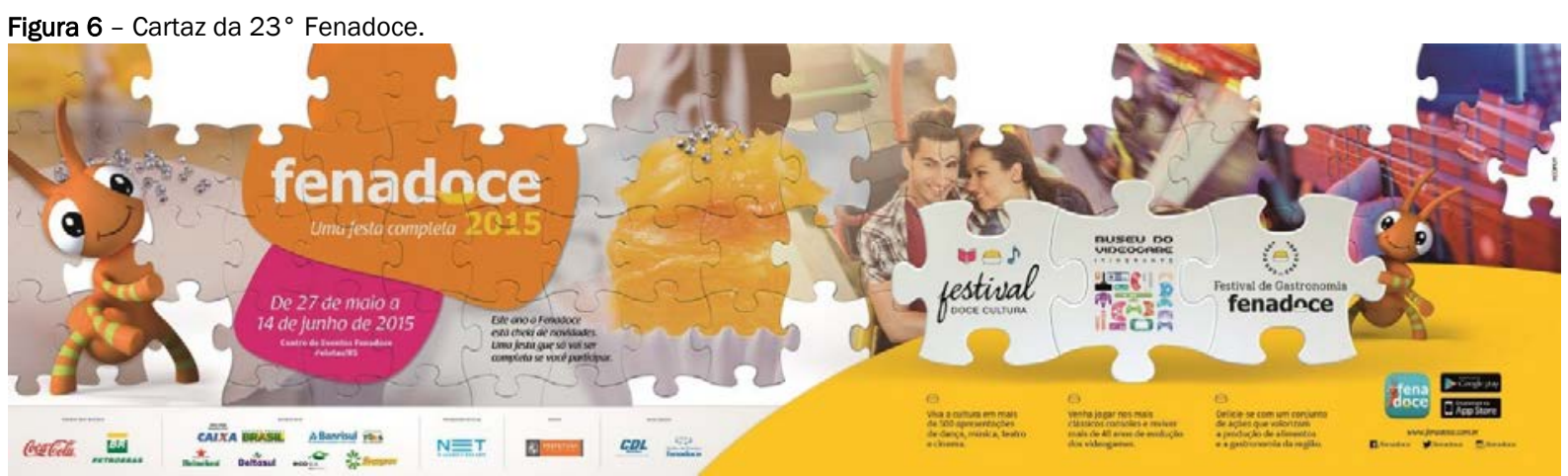

Fonte: http://www.incomum.in/blog/noticias/fenadoce-uma-festa-completa

Por fim, ainda em relação ao cartaz, o mascote e a logomarca do evento aparecem; e aparentemente o marketing utilizou a montagem do quebra-cabeça como representação de um evento que depende de uma série de pessoas, da comunidade e ações conjuntas para que aconteça e esteja completa.

\subsection{Campanha 2016 - $24^{\circ}$ Fenadoce}

A Fenadoce, em sua $24^{\circ}$ edição, comemorou 30 anos de existência. 0 tema foi "Para uma grande plateia, um grande espetáculo", evidenciando a importância das pessoas que prestigiam e sustentam as diversas formas culturais como a "plateia" - importante na construção e sustentação da diversidade cultural do município.

O cartaz apresenta as formigas carregando doces beijinho de coco e quindim, e no centro do material está o tema do evento. Percebe-se os doces como referência à identidade pela cultura doceira e ao patrimônio através do signo e significado.

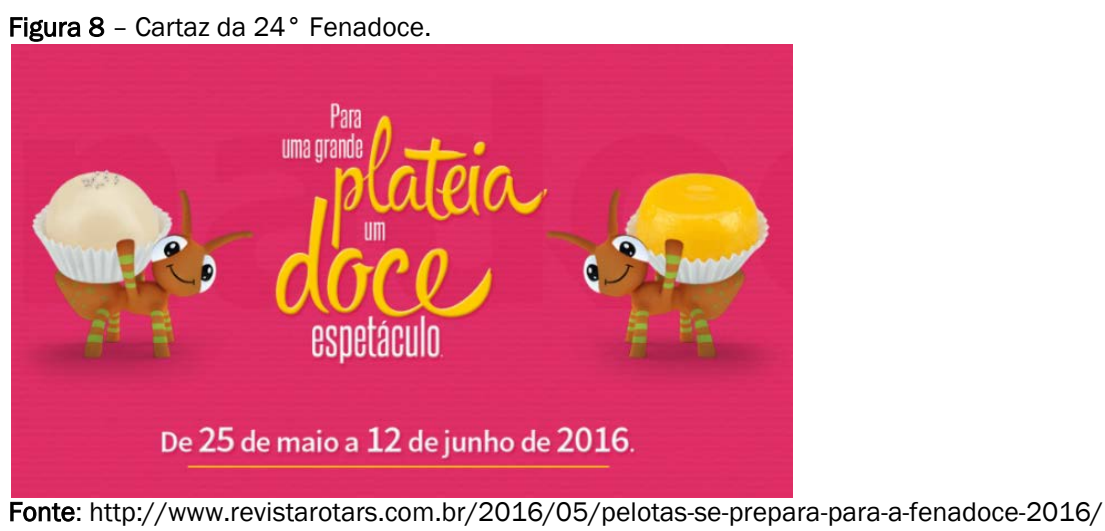

A propaganda segue o mesmo perfil do cartaz, a música destaca a importância das pessoas que prestigiam o evento e, por conseguinte, a diversidade cultural do município.

A plateia vem pra adoçar, o espetáculo vai começar. Pode vir, você vai sorrir. Fenadoce 2016, para uma grande plateia, um doce espetáculo. De 25 de maio a 12 de junho em Pelotas. A plateia vem pra adoçar, o espetáculo vai começar, é Fenadoce.

Nas imagens, as formigas surgem de um formigueiro e adentram a cidade, passando por imagens que simbolizam as artes e música (diversos artistas locais e regionais), circo (entende-se aqui a representação do Grupo Tholl de Pelotas) e teatro (Teatro Sete de Abril e Teatro Guarani) que fazem parte do contexto cultural de Pelotas, enquanto se dirigem ao evento Fenadoce representado por um grande quindim (patrimônio gastronômico). As imagens em gráficos simples traduzem a diversidade cultural do município entre bens materiais e imateriais. 


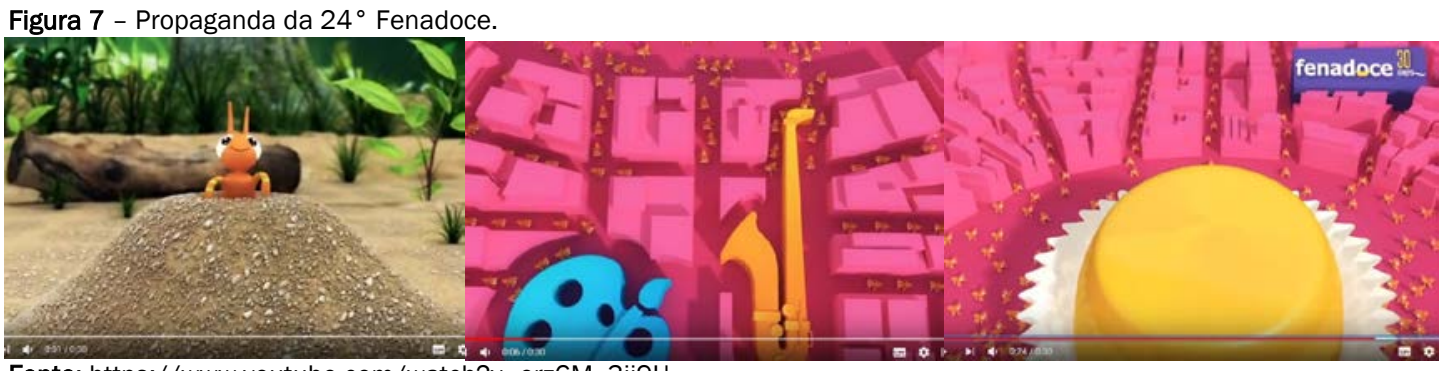

Fonte: https://www.youtube.com/watch?v=erz6M_3jigu

Embora de forma simplista, as imagens representam a cultura, os bens materiais e imateriais, as relações sociais, os signos e símbolos do patrimônio. 0 passeio das formigas pela cidade em direção à Fenadoce promete a vivência de uma experiência relacionada à identidade, onde a música complemente a mensagem.

O marketing é trabalhado com todas as subcategorias de forma mais ou menos evidente, sendo que a diferenciação não está presente nesta campanha. Estão presentes a logomarca somente no comercial, slogam e jingle.

\subsection{Campanha $2017-25^{\circ}$ Fenadoce}

Em 2017 ocorre inovação nas peças publicitárias, por terem sido criadas em conjunto com um artista local², Madu Lopez, que também ficou responsável pela elaboração de cenários e personagens vivos que contam a história e homenageiam as doceiras e a cultura pelotense com o tema "Doce, a nossa grande história".

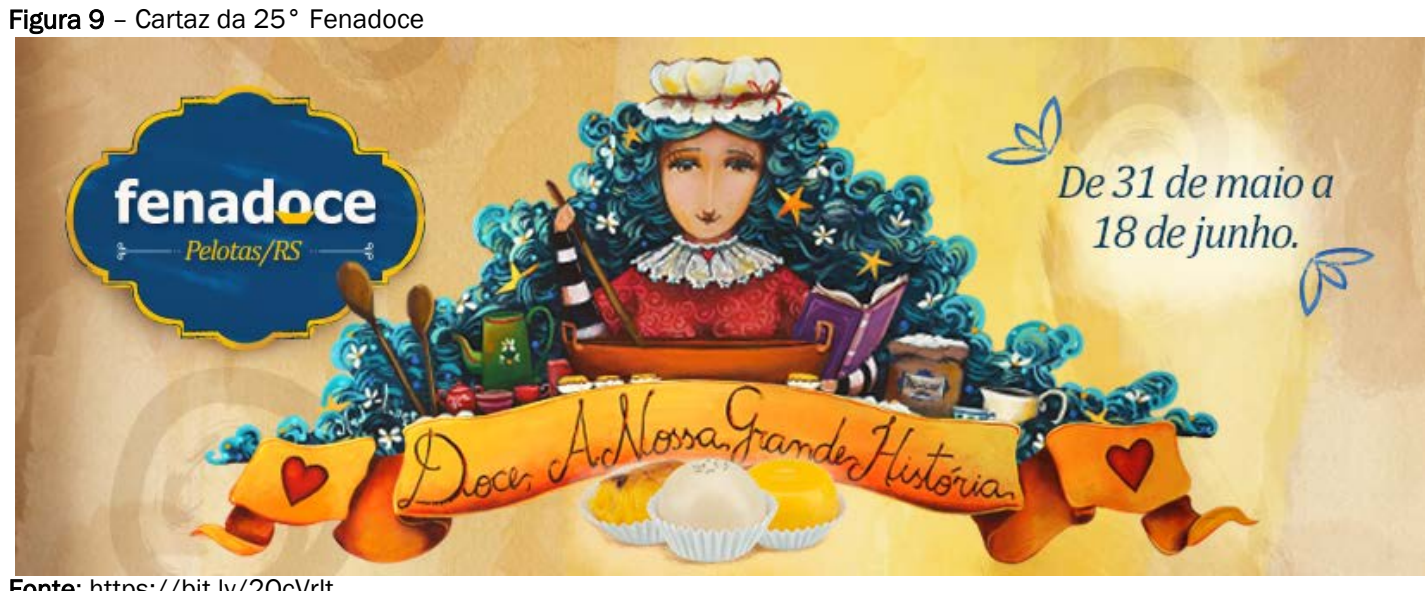

Fonte: https://bit.ly/2QcVrlt

O cartaz foi elaborado a partir da arte do pintor. Visualiza-se uma doceira, com um livro de receitas na mão, que mexe um tacho de cobre com uma colher de pau; açúcar e utensílios no entorno da bancada. A faixa traz o tema dessa edição e em primeiro plano há um beijinho de coco, quindim e trouxinha de amêndoas. Visualiza-se também a data do evento e a logomarca da feira.

A cultura, a identidade híbrida, a experiência e auto-identidade estão presentes tanto na imagem como no tema da campanha pelas palavras "doce" e a sentença "a nossa grande história". Os bens materiais e imaterias, a memória, os modos de criar, fazer e viver, os signos e símbolos do patrimônio estão presentes, assim como todas as categorias do marketing.

A propaganda inicia com a formiga abrindo um livro pop-up. Na primeira cena estão duas doceiras mexendo um tacho de cobre com colheres de pau, na mesa estão duas bandejas de doces, um pacote de açúcar e o cenário mostram móveis antigos; percebe-se, pela janela, que é de noite, representando o passado. A segunda cena se situa em uma confeitaria antiga, devido aos utensílios presentes, com doces e tortas dispostos na vitrine do balcão.

\footnotetext{
${ }^{2}$ Fenadoce (2017). Últimas Notícias. Conceito da 25a Fenadoce é uma criação do artista plástico Madu Lupes. Disponível em: https://bit.ly/2PK97TB
} 
Na terceira cena, duas doceiras estão em uma cozinha moderna (fogão a gás, liquidificador e batedeira), e possuem um livro de receitas dos doces, pelas janelas se observa que é de dia, representando o presente. $\mathrm{Na}$ confeitaria moderna, quarta cena, doces e tortas estão dispostos no balcão, um casal degusta doces e toma café, há um atendente atrás do balcão e a doceira pode ser vista pela janela da cozinha.

A quinta cena é ambientada em uma fábrica, personagens mexem tachos em um fogão à lenha, enquanto que, em primeiro plano, são finalizados doces de bandeja e são encaixotados doces de compota. A cena seguinte reporta à Fenadoce e à praça das doceiras com seus estandes em formato do patrimônio edificado pelotense. Observa-se um casal com uma bandeja de doces e roupas aristocráticas, dois vendedores e uma consumidora. Em primeiro plano estão dois bustos de doceiras e a faixa com a palavra "Fenadoce" e três docinhos tradicionais. O comercial finaliza com a formiga fechando o livro.

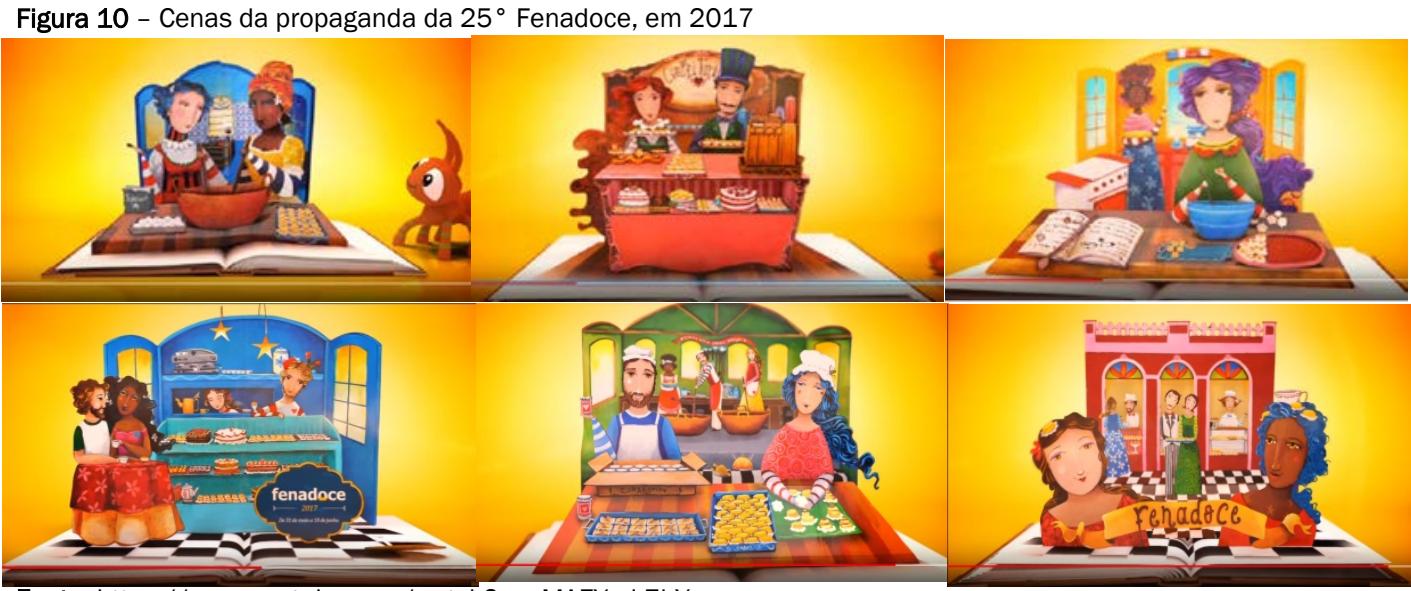

Fonte: https://www.youtube.com/watch?v=eMAEYmi-7hY

A música acompanha as imagens:

Era uma vez, o doce se fez, com tanto sabor, todo mundo adorou. Saiu do fogão, foi pro balcão, com água na boca, a nação conquistou. Fenadoce 2017, Doce, a nossa grande história. De 31 de maio a 18 de junho em Pelotas. Era uma vez, o doce se fez, com tanto sabor, todo mundo adorou. Saiu do fogão, foi pro balcão, com água na boca, a nação conquistou.

A propaganda e a música trazem todos os elementos relacionados ao patrimônio e à identidade de forma aprofundada, através de signos e símbolos. É possível entender a evolução da cultura doceira, dos modos de fazer de antigamente saindo de dentro das cozinhas para se tornarem fonte de renda e comercialização (modos de criar, fazer e viver, identidade híbrida). As relações sociais são percebidas através das diversas personagens que, de forma implícita, pelos diferentes trajes e cores, demonstram as diferentes etnias envolvidas (embora na propaganda não seja possível identificar os estereótipos), além da questão do universo feminino que envolve a feitura dos doces, a produção e o consumo, a experiência. A memória é representada pelos livros de receitas; o passado e o presente pela noite e o dia.

Nesta edição do evento foram utilizadas personagens humanas reais que representam as doceiras e suas etnias. Há personagens crianças, filhas das doceiras e duas personagens masculinas, entre eles, um confeiteiro. Essas personagens interagiam com o público no "Espaço Doce da Arte" localizado nos pavilhões do evento, um espaço com ambientação de uma confeitaria lúdica, esculturas e pinturas relacionadas à cultura doceira. 


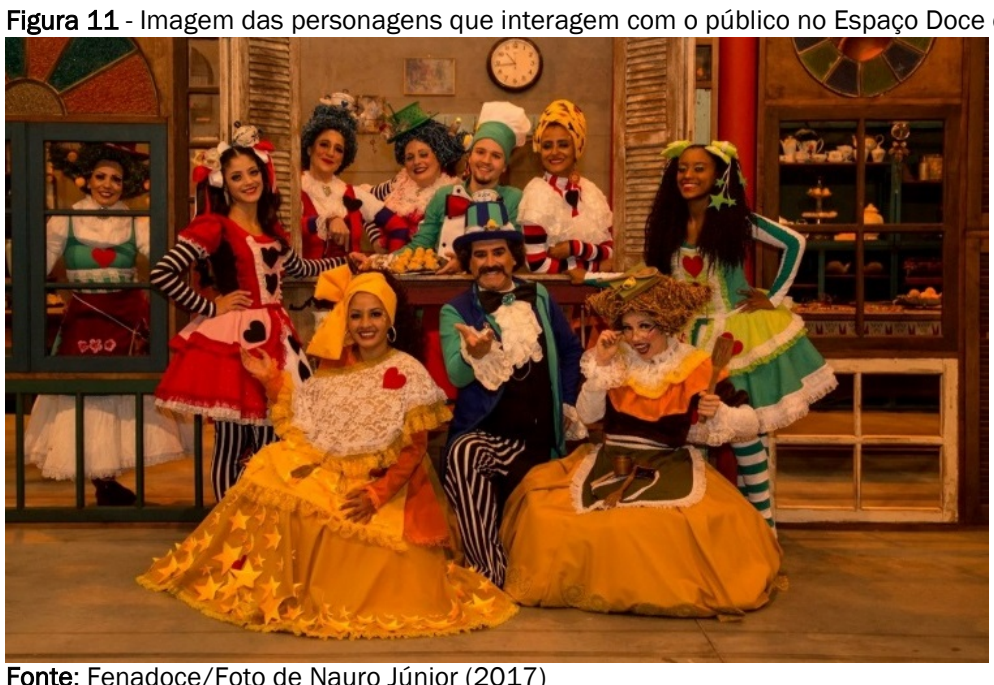

Destacam-se as duas personagens africanas, demonstrando a importância e reconhecimento da sua feitura nos doces, não somente como a mão-de-obra que mexia os tachos de doces (Kosby, 2007). Ademais, uma das personagens negras faz referência à religião africana.

Essa campanha, em relação às anteriores, foi a que melhor apresentou o universo que envolve o patrimônio imaterial gastronômico dos doces de Pelotas, pois diversos elementos aparecem nas peças publicitárias, decoração e personagens ligadas à cultura e identidade. Identifica-se um estudo minucioso da história a respeito desta gastronomia para a elaboração do material, pois todas as etnias foram possíveis de serem identificadas. É perceptível a valorização e reconhecimento do papel das africanas, além dos ciganos através dos tachos confeccionados e vendidos por eles, utensílio do antigo feitio dos doces.

É percebida a perpetuação e manutenção da cultura passada de geração em geração através dos livros de receita de família e as filhas das doceiras. Observa-se o quanto esse universo doceiro é feminino, pois as personagens masculinas aparecem principalmente como vendedores dos produtos.

Destaca-se na cena da fábrica referências aos doces de frutas. Há uma preocupação em evidenciá-los como parte da cultura doceira; portanto, não se apresentam somente os doces finos de origem portuguesa, que são os mais conhecidos pelo senso comum.

Resumidamente, as cenas mostram como os doces finos e doces coloniais formam o saber fazer do patrimônio imaterial em um universo primordialmente feminino, que se modificou ao longo do tempo e faz parte da economia local (identidade híbrida). Os doces finos e os doces de fruta formam o que hoje é conhecido como "Doces de Pelotas".

\section{DISCUSSÃO DOS RESULTADOS}

Feitas as análises das campanhas separadamente, parte-se para a análise cruzada das mesmas. Quanto aos aspectos relacionados às categorias e subcategorias do marketing: todas as campanhas utilizaram os recursos da marca logotipo da Fenadoce, tema (slogan) e os jingles nos vídeos das propagandas. Outras subcategorias percebidas após análise foram a propaganda de 30 segundos, o cartaz e o mascote Formiga.

0 mascote Formiga (juntamente com os doces de Pelotas) esteve presente em todos os materiais promocionais; algumas vezes as formigas representaram a personificação das pessoas (campanhas 2015 e 2016), as quais possibilitam a realização do evento e podem ser interpretadas, conforme Machado et al. (2011), como os consumidores, fornecedores e demais atores envolvidos. As formigas representaram as relações sociais que envolvem o saber fazer da cultura doceira e do evento.

Em todas as campanhas é possivel afirmar que houve trabalho de elaboração de crenças duradouras_da ideologia do marketing identificado pelos autores Crockett e Wallendorf (2004), Marion (2006) e Levy e Luedicke (2014), ao se relacionar o doce e o evento à promessa de uma experiência única (diferenciação). O principal destaque foi dado ao doce, como produto a ser consumido no evento. Portanto, constituindo-se 
a principal imagem percebida sobre o evento, uma vez que, conforme Buhalis (2000), a imagem é formada através das percepções e expectativas do turista. Entretanto, uma vez que a imagem deve ser uma articulação com a identidade cultural e participação dos residentes, como destacado por Zucco et al. (2017), somente as campanhas 2014 e 2017 tiveram maior preocupação em inserir a identidade e questões patrimoniais ligadas aos residentes de Pelotas.

Quanto à categoria identidade, às subcategorias identidade híbrida, auto-identidade, auto-associação e experiência, percebeu-se que todas as subcategorias estiveram presentes de forma mais ou menos evidente dependendo da campanha. A cultura doceira pelotense pode ser entendida como uma identidade híbrida (Hall 2006; Canclini, 2001), devido à mescla e intercâmbios culturais das diversas etnias envolvidas no universo dos doces de Pelotas. A auto-identidade e auto-associação são exploradas explicitamente no marketing através dos temas das campanhas de 2013 ("A nossa cultura está em festa”), 2014 (“Todos somos doces") e 2017 (“Doce, a nossa grande história") pela sensação de inclusão e pertencimento que as frases despertam. Partindo-se do pressuposto que os moradores e visitantes da região se identificam com a cultura doceira, também está presente o sentimento de pertencimento e ligação emocional com o evento (Tajfel, 1978 , 1979). Pode-se dizer que todas as campanhas buscam afirmar a experiência "doce" e prazerosa por vivenciar o evento.

Quanto à categoria patrimônio, o doce é o signo e símbolo patrimonial identificado em todas as campanhas pesquisadas; pela ótica do marketing, o mascote Formiga é o signo e símbolo que representa a marca do festival, ousa-se dizer que representa um grupo social que trabalha em conjunto para manter a cultura da comunidade. A cultura doceira é considerada um patrimônio imaterial com todas as subcategorias inseridas em seu contexto. Quanto à memória, as relações sociais e simbólicas, os modos de criar, fazer e viver são mais bem identificados nas campanhas de 2014, e principalmente na de 2017.

A campanha de 2017 foi um trabalho que representou a história relacionada à produção dos doces desde a sua origem dentro das cozinhas dos casarões até fazer parte do cotidiano de várias classes sociais, tornado fonte de renda no município. 0 vídeo explora o contexto social envolvido que o processo de inventariação identificou na busca por torná-lo patrimônio imaterial nacional, conforme foi identificado pela literatura (López-Guzmán et al., 2017; Brasil, 2010)

\section{CONSIDERAÇÕES FINAIS}

Os destinos e os eventos, ao serem inseridos no mercado competitivo passam a ser tratados como marcas que são trabalhadas pelos gestores de marketing, com objetivo de serem mais competitivos e despertarem o desejo de consumo, por serem vendidos como únicos e autênticos. Por outro lado, justamente pelas novas dinâmicas do mundo contemporâneo de identidades, cada vez mais fluidas, conforme propõe Giddes (2002), as marcas de lugares se tornam fonte de identificação dos moradores (Palmer et al, 2013; Wang et al. 2014).

Nesse sentido, as identidades e o patrimônio intimamente ligados às novas práticas sociais, mesmo em um processo de produção e consumo, devem ser legítimos e representar o sentido de identidade local dos residentes, sendo pautados pelos gestores de marketing, além da questão de capital e lucro. No âmbito do turismo, o marketing somente será legitimo quando demonstrar a relação com a memória, a identidade e o patrimônio dos moradores locais, pois a comunidade tem papel proativo na atividade, pois são eles que dão significado ao seu próprio lugar (Carvalho et al, 2011; Machado et al. 2011).

Ao se fazer a análise das cinco campanhas da Fenadoce em Pelotas/RS, os aspectos relacionados à identidade e patrimônio usados pelo marketing aparecem superficialmente, as referências à cultura doceira aparecem sem grandes detalhes nas campanhas de 2013, 2015 e 2016. O marketing do evento trabalhou principalmente com a promessa de uma experiência única do consumo dos doces de Pelotas conjuntamente com a divulgação da diversidade cultural pelotense.

Considerando o doce um signo carregado de simbologia (Horta, 2005; Cassier, 1968; Fernandéz, 2017) que evidencia valores e comportamentos implícitos, poder-se-ia afirmar que o patrimônio está presente em todas as campanhas, considerando-se a presença do doce. Porém, seriam necessárias pesquisas futuras sobre o quanto o doce tem a força de suscitar o imaginário patrimonial dos moradores e turistas. 
Sabendo-se que o patrimônio é entendido como um esforço de resguardar o passado no presente e para o futuro (Ferreira et al, 2008), a organização do evento busca manter o patrimônio vivo ao realizar as edições do evento, estando eles presentes ou não explicitamente nas peças publicitárias. Para tanto é imprescindível, conforme afirmou Zucco et al. (2017), que a promoção turística articule a imagem do destino/evento com a identidade cultural a partir da participação dos seus moradores. Portanto, questiona-se sobre quais parâmetros poderiam alicerçar o quanto as campanhas devem inserir aspectos mais aprofundados sobre a identidade, a memória e o patrimônio de uma cultura local, uma vez que eles são aceitos por alguns gestores envolvidos no evento e considerados legítimos pelos estudos de Nicolau Netto (2016) e Bourdieu (1996).

As campanhas elaboradas fazem parte das ações do marketing (os conhecidos 4Ps) do evento que constituem a marca e trabalho do branding. Embora esse estudo tenha focado na promoção do marketing, observaram-se limitações quanto às peças publicitárias promoverem o patrimônio imaterial, pois necessitam englobar os atributos intrínsecos e extrínsecos da marca que se pressupõe ser o patrimônio imaterial da cultura doceira. Principalmente por se tratar de branding de um festival, os valores identitários, culturais e patrimoniais necessitam serem estudados em todas as esferas gerenciais e estratégicas. Evidencia-se que, por se tratar de um patrimônio imaterial, torna-se um difícil trabalho de pesquisa, à luz do branding, bem como para o marketing. Com isso, limitações do marketing como promotor de patrimônio imaterial desdobram pesquisas futuras.

Outra indagação sobre essa prática de marketing, após a análise dos conteúdos, é quanto à necessidade de inovação e criatividade para a construção das campanhas. Porque elas acabam por influenciar na opção por material completamente diferente a cada ano, para que não seja repetitivo, o que pode evitar o desestimulo de curiosidade e desejo de consumo do evento.

Das cinco campanhas analisadas, destaca-se as campanhas de 2014 e principalmente de 2017. A campanha de 2017 apresentou elaboração aprofundada da história da gastronomia doceira pelotense, com diversos elementos que foram possíveis de identificar, inclusive em consonância com a literatura encontrada sobre o patrimônio imaterial relacionado aos doces de Pelotas. É possível afirmar que nessa campanha houve estudo para a elaboração dos materiais e intervenções pautados na identidade e no patrimônio imaterial dos doces de Pelotas. Partindo da afirmação que a identidade e o patrimônio devem ser passados nas mensagens de maneira que o residente consiga se ver representado, a campanha de 2017 foi a que se mostrou mais adequada.

Pelo referencial teórico apresentado e o resultado da pesquisa, esta investigação pode contribuir tanto para a gestão do evento como para o destino enquanto necessidade de evidenciar o valor patrimonial e identitário relacionado à cultura doceira em suas futuras campanhas.

O patrimônio é formado por signos e símbolos resultantes de valores e distinções advindos da consciência humana. Ao se questionar até que ponto as ações de marketing são legitimas quanto à ligação com a identidade e memória coletivas, onde tanto a comunidade como demais interessados consigam se reconhecer, esse estudo procurou compreender se o marketing considera os signos patrimoniais para a construção de uma marca e uma imagem nas suas peças publicitárias de forma que a comunidade se reconheça e se sinta inserida no processo.

Conclui-se que a relação entre patrimônio e marketing só será possível se a primeira categoria estiver inserida na segunda, ou seja, os símbolos e signos patrimoniais (aos quais estão englobadas as subcategorias de identidade e do próprio patrimônio) estejam inseridas na categoria marketing (imagem, ideologia e diferenciação). Academicamente, o método de análise de conteúdo, segundo Bardin (2011), mostrou-se eficiente na busca dessas reflexões; e permitiu elaborar as categorias e subcategorias de análise de conteúdo de materiais publicitários para averiguar o quanto o marketing considera a identidade e o patrimônio da comunidade. No entanto, são necessárias pesquisas futuras similares para consolidar as categorias e subcategorias encontradas.

Como limitação de pesquisa, pode-se julgar que a escolha das principais peças publicitárias que se repetiram a cada ano deixou de lado outros materiais de engajamento utilizados nas mídias sociais, matérias de jornais e televisão, além de demais atividades realizadas pelo evento que poderiam permitir um cenário mais com- 
pleto das estratégias utilizadas pelos gestores na manutenção da identidade e do patrimônio imaterial pelotense. Foram escassos os artigos encontrados que fizeram análises críticas relacionando as ações do marketing com o patrimônio, de maneira que estes dois campos necessitam serem trabalhados de forma mais adequada como alguns estudos na área do turismo já tem apontado (Zucco et al. 2017; López-Guzmán, 2017).

Além da averiguação das categorias e subcategorias encontradas, como pesquisas futuras, sugerem-se investigações complementares: com os gestores de marketing do festival para identificar os parâmetros por eles utilizados ao construir as campanhas relacionadas à identidade e patrimônio; investigar junto aos gestores do festival e gestores públicos como ocorre a participação no processo de elaboração das campanhas; e, em relação aos residentes, quanto o festival representa e como gostariam de serem representados nas ações de marketing do evento.

Agradecimentos: 0 presente trabalho foi realizado com apoio da Coordenação de Aperfeiçoamento de Pessoal de Nível Superior - Brasil (CAPES) - Código de Financiamento 001.

Nota: Parte deste trabalho foi apresentado em comunicação oral no Seminário Anptur 2018, realizado em São Paulo, Brasil, em setembro de 2018.

\section{REFERÊNCIAS}

Aaker, D. A. (2009). Managing brand equity: capitalizing on the value of a brand name. NY: Simon and Schuster.

Bagozzi, R. P. \& Dholakia, U. M. (2006). Antecedents and purchase consequences of customer participation in small group brand communities. International Journal of research in Marketing, 23, pp. 45-61. https://doi.org/10.1016/j.ijresmar.2006.01.005

Baker, W. E. (2003). Does Brand Name Imprinting in Memory Increase Brand Information. Psychology \& Marketing, Vol. 20(12), pp. 1119-1135. https://doi.org/10.1002/mar.10111

Bardin, L. (2011). Análise de conteúdo. São Paulo: Edições 70.

Bianchi, R. (2009). The "critical turn" in tourism studies: A radical critique. Tourism Geographies, 11(4), 484-504. https://doi.org/10.1080/14616680903262653

Bond, N.; Falk, J. (2013).Tourism and identity-related motivations: why am I here (and not there)? International Journal of Tourism Research, v. 15, n. 5, p. 430-442, 2013. https://doi.org/10.1002/jtr.1886

Brasil (2010). Legislação sobre patrimônio cultural. - Brasília: Câmara dos Deputados, Edições Câmara, 366 p.

Buhalis, D. (2000). Marketing the competitive destination of the future. Tourism Management 21(2000), 97-116. https://doi.org/10.1016/S0261-5177(99)00095-3

Buttle, H. \& Westoby, N. (2006). Brand Logo and Name Association : It's all in the Name. p. 1181-1194. https://doi.org/10.1002/acp.1257

Canclini, N. G. (2001). Culturas híbridas. Estratégias para entrar y salirde la modernidade. Nueva edición. PAIDÓS, Buenos Aires, Barcelona, México.

Canclini, N.G. (s/d). Cultura sem fronteiras. Entrevista com Reynaldo Damazio. Caderno de Leitura. Editora da Universidade de São Paulo - Edusp. Acesso em 03 de maio de 2018. Disponível em: http://www.edusp.com.br/cadleitura/cadleitura_0802_8.asp

Carvalho, R., Ferreira, A. M. \& Mota, L.F. (2011). O contributo dos eventos culturais e criativos para a criação de uma imagem diferenciadora do destino turístico maduro. 0 caso do festival Med de Loulé, Algarve. Book of Proceedings vol. I - International Conference on Tourism \& Management Studies -Algarve 2011. p. 457-566.

Cavalcanti, M. L. M. (2007). Açúcar no tacho. In: Quintas, F. (org) A civilização do Açúcar. Recife: Sebrae, Fundação Gilberto Freyre.

Crockett, D. \& Wallendorf, M. (2004). The Role of Normative Political Ideology in Consumer Behavior. Journal of Consumer Research, 31 (3), 511-528. https://doi.org/10.1086/425086

Dencker, A. (2003). Métodos e técnicas de pesquisa em turismo. São Paulo: Futura.

Do Valle, P. O., Mendes, J., \& Guerreiro, M. (2012). Residents' participation in events, events image, and destination image: a correspondence analysis. Journal of Travel \& Tourism Marketing, 29(7): 647-664. https://doi.org/10.1080/10548408.2012.720151

Fenadoce (2016). A receita mágica. Disponível em: https://www.fenadoce.com.br/texto/menu--a-feira 
Fenadoce (2017). Últimas Notícias: Fenadoce 2017 recebe mais de 280 mil pessoas e registra recorde na venda de doces. Disponivel em: https://bit.ly/2Q4TYgR

Ferreira, M. L. M, Cerqueira, F. V. \& Rieth, F. M. S. (2008). 0 doce pelotense como patrimônio imaterial: diálogos entre o tradicional e a inovação. Métis: história \& cultura, 7(13): 91-113.

Figueiredo, M. D. D. (2013). A transmissão do saber-fazer como intencionalidade incorporada: etnografia em uma fábrica de doces em Pelotas, RS. Tese de doutorado. Universidade Federal do Rio Grande do Sul.

Freyre, G. (1997). Açúcar: uma sociologia do doce, com receitas de bolos e doces do Nordeste do Brasil. [S.I.]: Companhia das Letras.

Giddens, A. (2002). Modernidade e Identidade. 1. ed. Rio de Janeiro: Zahar Ed

Gil, A. C. (2008). Métodos e técnicas de pesquisa social. 6. ed. Ediitora Atlas SA.

Hall, S. (2006). A identidade cultural na pós-modernidade (11 ed.). Rio de Janeiro: DP\&A.

Hannam, K.; Sheller, M.; Urry, J. (2006). Editorial: mobilities, immobilities and mooring. Mobilities, London, 1(1): 1-22. https://doi.org/10.1080/17450100500489189

Haobin Ye, B. et al.(2014). Does social identity affect residents' attitude toward tourism development? An evidence from the relaxation of the Individual Visit Scheme. International Journal of Contemporary Hospitality, 26 (6): 907-929. https://doi.org/10.1108/IJCHM-01-2013-0041

Hearly, M. (2009). O que é branding? SL, Barcelona.: Editorial Gustavo Gili.

Horta, M. P. (2005). Lições das coisas: o enigma e o desafio da Educação Patrimonial. Revista do Patrimônio Histórico e Artístico Nacional, pp. 220-233.

IPHAN (2007). Patrimônio Vivo - Pelotas/RS. Série Preservação e Desenvolvimento - Monumenta. Brasília, DF: IPHAN / Programa Monumenta, v.7, 116p.

IPHAN (2018). Tradições Doceiras de Pelotas (RS) é reconhecida como Patrimônio Imaterial do Brasil. Assessoria de Comunicação Iphan. Acesso em: 18 de maio de 2018. Disponivel em: https://bit.ly/2KLZWjm

Ismail, S., Ahmad, Y., \& Hamzah, H. (2008). Heritage conservation for city marketing: The imaging of the historic city of Georgetown, Penang. Journal of Design and Built Environment, 4(1): 27-40.

Janonis, V., Dovalienè, A., \& Virvilai, R. (2007). Relationship of Brand Identity and Image. Engineering Economics, 51(1).

Kapferer, J. N. (2008). The New Strategic Brand Management: Creating and Sustaining Brand Equity long term. London: Kogan Page.

Keller, K. L., Aperia, T., \& Georgson, M. (2008). Strategic brand management: A European perspective. Edinburgh, Scotland: FT Prentice Hall.

Kosby, M. F. (2007). "Aqui nós cultivamos todas as doçuras”: a contribuição negra para a tradição doceira de Pelotas. Monografia. Bacharelado em Ciências Sociais. Instituto de Sociologia da Universidade Federal de Pelotas.

Kotler, P. (2006). Kotler on Marketing: How to create, win, and dominate markets. NY: Simon and Schuster.

Laing, J., Wheeler, F., Reeves, K. \& Frost, W. (2014). Assessing the experiential value of heritage assets: A case study of a Chinese heritage precinct, Bendigo, Australia. Tourism Management, 40, 180-192. https://doi.org/10.1016/j.tourman.2013.06.004

Landa, R. (2006). Designing brand experience. Clifton Park, NY: Thomson.

Lavandoski, J., Tonini, H., \& Barreto, M. (2012) Uva, vinho e identidade cultural da Serra Gaúcha (RS, Brasil). Revista Brasileira de Pesquisa em Turismo 6(2), 216-232. https://doi.org/10.7784/rbtur.v6i2.529

Lee, A., Yang, J., Mizerski, R., \& Lambert, C. (2015). The strategy of global branding and brand equity. Routledge. https://doi.org/10.4324/9781315722528

Levy, S. J. \& Luedicke, M. K. (2013). From marketing ideology to branding ideology. Journal of macromarketing, 33(1), 58-66. https://doi.org/10.1177/0276146712459656

López-Guzmán, T., Prada-Trigo, J., Pérez-Gálvez, J. C, \& Pesantez, S. (2017). El patrimonio inmaterial de la humanidad como herramienta de promoción de un destino turístico. Estudios y perspectivas en turismo, 26(3), 568-584.

Machado, D. F. C, Medeiros, M.de L. \& Luce, F. B. (2011). A miopia do marketing de destinos turísticos. Book of Proceedings vol. I -International Conference on Tourism \& Management Studies -Algarve 2011, 654-663.

Marion, G. (2006). Research Note: Marketing ideology and criticism: Legitimacy and legitimization. Marketing Theory, 6(2), 245-262. https://doi.org/10.1177/1470593106063985

McLuhan, M. (1964). Understandig media. The Extensions of Man. New York: New American library.

McLuhan, M. (1994). Understanding media: The extensions of man. MIT press. 
Nicolau Netto, Michel (2016). O Discurso do Marketing de Lugar e os Grandes eventos. Caderno CRH, 29 (78), 495512. https://doi.org/10.1590/s0103-49792016000300006

Palmer, A., Koenig-Lewis, N., \& Jones, L. E. M. (2013). The effects of residents' social identity and involvement on their advocacy of incoming tourism. Tourism Management, 38, 142-151. https://doi.org/10.1016/j.tourman.2013.02.019

Prodanov, C., \& Freitas, E. (2009). Metodologia do Trabalho Científico: Métodos e Técnicas da Pesquisa e do Trabalho Acadêmico. Novo Hamburgo: Feevale.

Ramos, G. D. \& Fernandes, J. J. (2014). Tendências Recentes em Turismo: algumas reflexões na perspectiva dos Territórios de Baixa Densidade. Cogitur, Journal of Tourism Studies.

Reed II, A., Forehand, M. R., Puntoni, S., \& Warlop, L. (2012). Identity-based consumer behavior. International Journal of Research in Marketing, 29(4), 310-321. https://doi.org/10.1016/j.ijresmar.2012.08.002

Rossi, U. \& Vanolo, A. (2012). Urban political geographies. A global perspective. London: Sage. https://doi.org/10.4135/9781446288948

Smith, M., \& Puczkó, L. (2012). Budapest: from socialist heritage to cultural capital? Current Issues in Tourism, 1-2, pp. 107-119. https://doi.org/10.1080/13683500.2011.634898

Su, R., Bramwell, B., \& Whalley, P. A. (2018). Cultural political economy and urban heritage tourism. Annals of Tourism Research, 68, 30-40. https://doi.org/10.1016/j.annals.2017.11.004

Tajfel, H. (1978). The social psychology of minorities. New York: Minority Rights Group.

Tello Fernández, M. I. (2017). Entre signo y símbolo: una diferencia que afecta la axiología del patrimonio cultural inmueble.Gremium,4 (8): 81-96.

Urry, J. (1996). O olhar do turista. Lazer e viagens nas sociedades contemporâneas. SESC e Studio Nobel, São Paulo.

Veal, A. J. (2011). Metodologia de pesquisa em lazer e turismo. São Paulo: Aleph.

Wang, S., Zhou, L., Lee, S., \& King, C. (2014). Analysis of Residents' Social Identity, Tourism Engagement, and Propensity for Tourism Advocacy. Advances in Hospitality and Leisure, 10, pp. 109-129. https://doi.org/10.1108/S1745354220140000010006

Zucco, F. D., de Quadros, C. M. B., Schmitt, J. R., \& Fiuza, T. F. (2017). Imagem e identidade turísticas relacionadas às práticas e bens culturais percebidas pelos residentes: perspectivas a partir da cidade de Blumenau, Santa Catarina, Brasil. Revista Brasileira de Pesquisa em Turismo, 11(2), 320-346. https://doi.org/10.7784/rbtur.v11i2.1309

\section{Informations of the authors}

\section{Cristiane Berselli}

Mestre pelo Programa de Pós-Graduação em Turismo e Hotelaria da Universidade do Vale do Itajaí (UNIVALI), Balneário Camboriú, Brasil. Bolsista da Coordenação de Aperfeiçoamento de Pessoal de Nível Superior (CAPES), Balneário Camboriú, Brasil. Especialista em Gestão Pública e Desenvolvimento Regional pela Universidade Federal de Pelotas, Brasil. Bacharel em Turismo e Tecnóloga em Hotelaria pela Universidade Federal de Pelotas, Brasil. Endereço Postal: $5^{\mathrm{a}}$ Avenida, 1.100 - Bloco 07 - sala 206 - Bairro: Municípios. CEP 88337-300 Balneário Camboriú-SC - Brasil.

Contribuição do autor: concepção da idéia, construção teórica, redação, obtenção dos dados e resultados e conclusão. E-mail: cristiane.berselli@gmail.com

ORCID: 0000-0002-9121-6100

\section{Luciano Torres Tricárico}

Mestre e doutor em Arquitetura e Urbanismo pela Universidade de São Paulo (USP), Brasil. Trabalha como professor e pesquisador na Universidade do Vale do Itajaí, Balneário Camboriú, Brasil; e como Coordenador do Laboratório de Paisagismo Aplicado (LaPa) da Universidade do Vale do Itajaí (UNIVALI), Balneário Camboriú, Brasil. Endereço Postal: $5^{a}$ Avenida, 1.100 - Bloco 07 - sala 204 - Bairro: Municípios. CEP 88337-300 Balneário Camboriú-SC - Brasil. Contribuição do autor: revisão teórica e revisão dos resultados.

E-mail: tricarico@univali.br

ORCID: 0000-0003-3307-8229

\section{Diva de Mello Rossini}

Pós-doutora em Arquitetura pela Universidade de Lisboa (2014). Doutora em Administração e Turismo pela Universidade do Vale do Itajaí (2012). Professora Titular da Universidade do Vale do Itajaí, Balneário Camboriú, Brasil. Dirección Postal: 5a Avenida, 1.100 - Bloco 07 - sala 204- Bairro: Municípios. CEP 88337-300 Balneário Camboriú-SC - Brasil.

Contribuição do autor: revisão teórica.

E-mail: divarossini@univali.br

ORCID: 0000-0002-9050-6587 